See discussions, stats, and author profiles for this publication at: https://www.researchgate.net/publication/304745263

\title{
Production of Fungal Laccase Using Orange Peelings as Substrate by Submerged Static Fermentation
}

Article · January 2016

DOI: 10.9734/BMRJ/2016/27257

CITATIONS

3

2 authors:

Francis SIre

University of Port Harcourt

24 PUBLICATIONS 142 CITATIONS

SEE PROFILE
READS

291

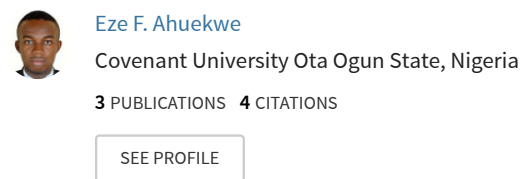

Some of the authors of this publication are also working on these related projects:

Production of Fungal Laccase using Organic and Inorganic Feed Substrates by Submerged Static Fermentation View project

Production of Sophorolipid biosurfactants from Indigenous Sources for Industrial Applications View project 


\title{
Production of Fungal Laccase Using Orange Peelings as Substrate by Submerged Static Fermentation
}

\author{
Francis Sopuruchukwu Ire ${ }^{1^{*}}$ and Eze Frank Ahuekwe ${ }^{1}$ \\ ${ }^{1}$ Department of Microbiology, Faculty of Science, University of Port Harcourt, P.M.B. 5323, Choba, \\ Port Harcourt, Nigeria.
}

Authors' contributions

This work was carried out in collaboration between both authors. Author FSI designed the study, provided technical expertise, performed the statistical analysis and proofread the manuscript. Author EFA wrote the protocol, managed the analyses of the study and wrote the first draft of the manuscript. Both authors managed the literature searches. Both authors read and approved the final manuscript.

Article Information

DOI: 10.9734/BMRJ/2016/27257

Editor(s):

(1) Vijay Kumar Eedunuri, Greehey Children's Cancer Research Institute, UT Health Sciences Center, San Antonio,Texas,

USA.

Reviewers:

(1) Ali Mohamed Elshafei, Division of Genetic Engineering \& Biotechnology, National Research Centre, Egypt.

(2) C. S. Karigar, Bangalore University, Bangalore, India. Complete Peer review History: http://sciencedomain.org/review-history/15210

Original Research Article

Received 26 ${ }^{\text {th }}$ May 2016

Accepted $17^{\text {th }}$ June 2016

Published $29^{\text {th }}$ June 2016

\section{ABSTRACT}

Aims: Laccases are diphenol oxidases that have numerous applications in biotechnological processes. In this work, the production of fungal laccase using organic and inorganic feed substrates in submerged static fermentation was investigated.

Study Design: One-factor-at-a-time strategy was adopted to optimize the cultural parameters for enhanced laccase production.

Place and Duration of Study: Department of Microbiology, Faculty of Science, University of Port Harcourt, Nigeria, between October 2014 and November 2015.

Methodology: A total of nine fungal isolates were obtained from wood decaying sites of University of Port Harcourt forest areas and subjected to laccase screening with 2,2-Azinobis-3ethyl(benzthiazoline-6-sulphonate) (ABTS). The influence of medium components using the basal medium at $\mathrm{pH} 5.0$ as base was evaluated and these cultural parameters include carbon sources (glycerol, rice bran, glucose and ground orange peelings), nitrogen sources (yeast extract, 
potassium nitrate, peptone and ammonium chloride), metal ions (copper sulfate and manganese sulfate) and inducer compounds (ABTS, Tween 80 and soya oil). Time course study was conducted with the unoptimized and optimized cultural medium.

Results: Out of nine cultures tested, seven were found to be laccase-positive with isolates CF-1 and CF-2 being the best potential cultures. Isolate CF-1 which had the highest laccase activity was identified as Pleurotus ostreatus and was chosen for further studies. Ground orange peelings $(0.1 \%$ $\mathrm{w} / \mathrm{v})$ and $\mathrm{NH}_{4} \mathrm{Cl}(0.1 \% \mathrm{w} / \mathrm{v})$ were the most suitable carbon and nitrogen source for laccase production by the fungus. Maximum laccase production was obtained with $\mathrm{Cu}^{2+}$ at a concentration of $0.05 \% \mathrm{w} / \mathrm{v}$ among other metal ions. Soya oil at concentration of $0.05 \%(\mathrm{v} / \mathrm{v})$ was the best inducer of the enzyme. The highest laccase production was achieved at an Initial $\mathrm{pH} 4.5$. Under optimal culture medium, the maximum laccase activity was determined to be $7.21 \mathrm{U} \mathrm{ml}^{-1}$ on the 7th day of cultivation; which was approximately three times higher than that in basal medium $\left(2.5 \mathrm{U} \mathrm{ml}^{-1}\right)$. The results obtained indicate that the extracellular laccase production is dependent on various cultural parameters.

Conclusion: One-factor-at-a-time strategy adopted in this study proved that the optimum conditions enhanced laccase production by three folds using orange peelings. The results obtained are very interesting since orange peelings are common agricultural wastes in several countries and imply that their re-utilization in the production of enzymes would help solve pollution problems caused by their improper disposal. In addition, Pleurotus ostreatus having shown promise for laccase production using low-cost lignocellulosic substrates could be suggested as a prospective candidate for higher laccase production for several biotechnological applications.

Keywords: Laccase; ABTS; Pleurotus ostreatus; submerged fermentation; static; orange peels.

\section{INTRODUCTION}

Laccases (1,4-benzenediol: oxygen oxidoreductase; EC 1.10.3.2) are multi-copper polyphenol oxidases that catalyse the one electron enzymatic oxidation of a wide variety of both organic and inorganic substrates with the concurrent four electron reduction of oxygen to two water molecules [1,2]. They are among the important enzymes that have attracted tremendous attention in recent years due to their important applications in different industries [3]. Along with the plant ascorbate oxidases and the mammalian plasma proteins, they belong to a group of enzymes called the Blue Copper proteins due to their characteristic four (4) catalytic copper atoms [4]. As such, the laccase molecule is a dimeric or tetrameric glycoprotein with four copper atoms distributed in three (3) redox sites with one copper atom placed at the Type 1 site, where reducing substrates bind. The other three copper atoms are clustered in the Type 2/Type 3 trinuclear site, where the reduction of molecular oxygen and the eventual release of water take place $[5,6]$.

The broad substrate specificity of laccases holds promise to use them for biotechnological purposes, such as biomechanical pulping, bleaching of pulp, degradation of dye, and transformation and detoxification of xenobiotic and other aromatic compounds [7]. Numerous studies have shown the potential of fungal phenol oxidases as a biological alternative for chemical oxidative process like in pulp delignification, textile industries, food industries, organic synthesis, pharmaceutical sector, bioremediation and nanobiotechnology [8]. Laccase production by white-rot fungi is often associated with their lignin degrading abilities, although laccases play a role in some other functions such as sporulation, pigment production and fruiting body development [1]. Laccases have been isolated from many plants, fungi, actinomycetes and bacteria [9]. Most of the laccase studies are of fungal origin especially from white rot fungi [10-17]. Pleurotus ostreatus is one of the most extensively studied white-rot fungi as potential laccase producers for its exceptional ligninolytic properties; fast growth and easy handling under field conditions [3]. Screening of a large number of white rot fungi is necessary to select strains that are able to produce high titres of laccases with novel characteristics. Production of laccase by microorganisms has been carried out in both submerged and solid state fermentation [18]. Under the submerged fermentation, static or agitated conditions could be used for the cultivation of the organism for enzyme production. Previous reports indicated that high titre of laccase has been obtained with static conditions than agitated fermentation processes [19]. 
The application of laccases in biotechnological processes requires the production of high amounts of enzyme at low costs, as such the current focus of laccase research is oriented towards the search for efficient production systems. In addition, production of laccase is affected by many typical fermentation conditions such as medium composition, carbon and nitrogen ratio, $\mathrm{pH}$, temperature and aeration rate [20]. In particular, the selection of appropriate medium components and use of inexpensive sources (industrial and agricultural wastes) for laccase production is crucial in the development of an efficient and economic process. According to Cilerdzic et al. [21] agricultural and industrial expansion has led to the production of large amounts of agricultural, forest, industrial and domestic wastes which invariably could pose serious environmental pollution. This informed the decision to evaluate rice bran and orange peel for their potential as sole carbon source for laccase production by fungi. Fungal laccase production is highly regulated by the media composition and hence medium optimization has become one of the main methods to enhance laccase production [22]. Therefore, this present study was aimed at isolation, screening of potential laccase producing fungi and assessing the ability of selected agro-waste residues for laccase production as well as optimize the laccase production by $P$. ostreatus under submerged static conditions using One-Factorat-a-Time methodology.

\section{MATERIALS AND METHODS}

Soil samples were collected from different wood decaying sites in forest areas of University of Port Harcourt, Choba, Rivers State at $5-10 \mathrm{~cm}$ depth into sterile nylon bags.

\subsection{Isolation and Screening of Fungal Strain}

One gram of dried soil sample was diluted ten times in $9 \mathrm{ml}$ sterile distilled water by the method of Gochev and Krastanov [23] before plating on Potato Dextrose Agar, Soil Extract Agar and Malt Extract Agar, all fortified with $0.05 \mathrm{mg} / \mathrm{ml}$ Chloramphenicol and incubated at $30^{\circ} \mathrm{C}$ for 7 days. Isolates were subjected to laccase screening on Malt Extract Agar fortified with $0.25 \mathrm{mg} / \mathrm{ml}$ ABTS (2,2-Azinobis-3ethyl(benzthiazoline-6-sulphonic acid)) as an indicator [24,25]. Isolates with the highest laccase activity were chosen and identified microscopically on a wet mount where the shape, size and arrangement of the conidiophores and conidiospores were studied. The morphological examinations were observed on PDA and Glucose-MEA with reference to the standards of Samuels et al. [26] and subsequently maintained as slants on a Glucose-MEA. These slants were sub-cultured every two (2) weeks.

\subsection{Basal Medium Composition}

The medium of Gochev and Krastanov [23] was used as basal medium to assess the ability of the fungus to produce laccase in liquid medium. The basal medium consisted of $10 \mathrm{~g}$ Glucose, $1 \mathrm{~g}$ $\mathrm{KH}_{2} \mathrm{PO}_{4}, 0.5 \mathrm{~g} \mathrm{MgSO}_{4} .7 \mathrm{H}_{2} \mathrm{O}, 0.1 \mathrm{~g} \mathrm{CaCl}_{2} .2 \mathrm{H}_{2} \mathrm{O}$, $0.005 \mathrm{~g} \mathrm{FeSO}_{4} .7 \mathrm{H}_{2} \mathrm{O}, 0.3 \mathrm{~g}\left(\mathrm{NH}_{4}\right)_{2} \mathrm{SO}_{4}, 0.005 \mathrm{~g}$ $\mathrm{ZnSO}_{4} .7 \mathrm{H}_{2} \mathrm{O}, 0.5 \mathrm{~g} \mathrm{KCl}, 0.5 \mathrm{~g}$ peptone per litre. Medium was adjusted to $\mathrm{pH}$ 5.0. The soil-derived basidiomycete Pleurotus ostreatus was used as the laccase source. Fungal spore suspension prepared by homogenizing the $96 \mathrm{~h}$ old freshly grown slants with $2 \mathrm{ml}$ sterile distilled water for $5 \mathrm{~s}$ was used as the inoculum. One millilitre $(1 \mathrm{ml})$ inoculum $(2 \% \mathrm{v} / \mathrm{v})$ was introduced into $250 \mathrm{ml}$ Erlenmeyer flasks containing $50 \mathrm{ml}$ basal medium and incubated at $30^{\circ} \mathrm{C}$ for 5 days under submerged static condition. After every $24 \mathrm{~h}$ of cultivation, samples were prepared by filtration using Whatman No. 1 filter paper. The obtained cell free supernatant was used for the determination of laccase activity.

\subsection{Effect of Carbon Sources on Laccase Production}

Various carbon sources such as glycerol, rice bran and orange peel at $0.5 \%(\mathrm{w} / \mathrm{v})$ were separately added in place of glucose as sole carbon sources in the basal culture medium of the fungus for optimization of the carbon source [24].

\subsection{Effect of Nitrogen Sources on Laccase Production}

Different concentrations of organic and inorganic nitrogen sources were examined for maximum production of laccase. Peptone in the basal medium containing the best carbon source was replaced with varying concentration $(0.1-1.0 \%$ $(\mathrm{w} / \mathrm{v})$ of potassium nitrate $\left(\mathrm{KNO}_{3}\right)$, ammonium chloride $\left(\mathrm{NH}_{4} \mathrm{Cl}\right)$ and yeast extract using the method of D'Souza-Ticlo et al. [27]. 


\subsection{Effect of Copper and Manganese lons on Laccase Production}

Copper ion $\left(\mathrm{Cu}^{2+}\right)$ and Manganese ion $\left(\mathrm{Mn}^{2+}\right)$ at varying concentrations $(0.05-0.1 \% \mathrm{w} / \mathrm{v})$ each were incorporated into the fermentation medium containing the best concentrations of carbon and nitrogen sources, according to the method of Liu et al. [25].

\subsection{Effect of Inducers on Laccase Production}

Soya oil, Tween 80 and ABTS as inducer compounds were incorporated into the fermentation medium containing the best concentrations of the carbon and nitrogen sources, and metal ion according to the method of Osma et al. [28].

\subsection{Effect of Initial pH on Laccase Production}

The effect of $\mathrm{pH}$ on laccase production was studied by adjusting the $\mathrm{pH}$ of the medium between $\mathrm{pH} 4.0$ to 8.0 with $0.1 \mathrm{~N} \mathrm{NaOH}$ or $0.1 \mathrm{~N}$ $\mathrm{HCl}$ before sterilization [29]. Fermentation was carried out at conditions earlier mentioned using orange peels and ammonium chloride as carbon and nitrogen sources, respectively.

\subsection{Time Course Study of Laccase Production}

The influence of time course on the production of laccase was examined with the optimized medium parameters which comprised of $0.1 \%$ $(\mathrm{w} / \mathrm{v})$ orange peelings, $0.1 \%(\mathrm{w} / \mathrm{v}) \mathrm{NH}_{4} \mathrm{Cl}, 0.05 \%$ $(\mathrm{w} / \mathrm{v}) \mathrm{CuSO}_{4}$ and $0.5 \%(\mathrm{v} / \mathrm{v})$ soya oil and initial $\mathrm{pH} 4.5$ that favoured high laccase production. Fermentation was carried out by incubating the fungus at $30^{\circ} \mathrm{C}$ for different time periods of nine days and after each $24 \mathrm{~h}$ of incubation, the final $\mathrm{pH}$, biomass yield and laccase activity were determined using standard methods.

\subsection{Analytical Methods}

\subsubsection{Enzyme activity}

Laccase activity was estimated spectrophotometrically at $420 \mathrm{~nm}$ as described by Birhanli et al. [13] with modifications using ABTS (2,2-Azinobis-3-ethyl(benzthiazoline-6sulphonate)) as a substrate. The assay mixture contained $1.50 \mathrm{ml} \mathrm{Na}$-Acetate buffer $(0.1 \mathrm{M}) \mathrm{pH}$
$5.0,1.00 \mathrm{ml}$ cell-free culture filtrate and $0.50 \mathrm{ml}$ ABTS (0.1 M). Oxidation of ABTS was monitored by an absorbance increase at $420 \mathrm{~nm}$ at $30^{\circ} \mathrm{C}$. The blank contained all the assay constituents except the active enzyme while buffer or heat inactivated enzyme was used in its place. Enzyme activity was expressed as $\mathrm{U} / \mathrm{ml}$. One activity unit was defined as the amount of enzyme producing a 0.001 increase in the optical density per $\mathrm{ml}$ per minute of the culture filtrate $(\mathrm{U} / \mathrm{ml})$ under the standard reaction condition [27]. All values were the means of three replicates, with standard deviation of the means shown as \pm values.

\subsubsection{Fungal identification}

The isolated fungi were identified on the basis of morphological (macro and micro) and physiological characteristics as described by Aneja [30]. The following morphological characteristics were examined and used to identify the fungus: colony growth, presence or absence of aerial mycelium, colony colour, presence of wrinkles and furrows, pigment production among others [31]. Also the spore structure of the fungal isolates was stained by cotton blue and Lactophenol [32] observed under compound microscope with reference to standard atlas and manuals.

\subsubsection{Biomass evaluation}

The fungal biomass was recovered after fermentation by filtration using a pre-weighed Whatman No. 1 filter paper. Thereafter, the mycelial mat in the pre-weighed Whatman No. 1 filter paper was dried at $70^{\circ} \mathrm{C}$ until a constant weight is obtained. The difference in weight between the pre-weighed filter paper and mycelial mat-bearing Whatman No. 1 filter paper represented the biomass of fungal mat and expressed in gram fungal dry weight per $50 \mathrm{ml}$ of medium (g/50 ml) [28].

\subsection{Statistical Analysis}

The data obtained in this study was subjected to statistical analysis using single factor analysis of variance (ANOVA) at a significance level of $\mathrm{p}<0.05$.

\section{RESULTS AND DISCUSSION}

This study was aimed at isolation and screening of potent laccase producing fungi as well as 
evaluation of various physicochemical parameters to optimize laccase production under submerged static conditions. Among the 30 samples collected, 7 strains out of 9 fungal isolates were selected as positive organisms which formed varied degrees of a reddish-brown coloured zone around the colonies. Based on the reddish brown zones, seven strains were designated as CF-1 to CF-7 (Table 1). Strain CF1 having the highest diameter of decolourized zone was selected for further studies. The result obtained is in agreement with the report of Kiiskinen et al. [33] for the isolation of laccase producing fungus. Morphological examinations presented them as cottony-white eccentric colonies on MEA covering plate, with a light brown reverse side. The isolates were nonsporulating with abundant clamp connections forming in mycelia, a microscopical characteristic of basidiomycetes. This isolate was tentatively identified as Pleurotus ostreatus.

\subsection{Laccase Production Using Basal Medium}

Fig. 1 shows laccase production by $P$. ostreatus using the basal medium in a 5 day time course study with unoptimized medium. Results obtained show that laccase secretion by this fungus commenced after $24 \mathrm{~h}$ of cultivation. The result indicated that maximum laccase activity $\left(2.5 \mathrm{U} \mathrm{ml}^{-1}\right)$ occurred on the $4^{\text {th }}$ day of incubation at $\mathrm{pH}$ 5.6. Also, the highest growth of the fungus was obtained on day 4. Further incubation beyond the fourth day resulted to decrease in laccase activity and growth of the fungus. It could be suggested that the low $\mathrm{pH}$ and low glucose (from the basal medium) may have caused an early but slow laccase secretion with a corresponding slow biomass increase. This result is consistent with earlier reports of Galhaup et al. [34].

\section{Table 1. Screening of laccase-producing fungi by plate tests using the indicator compound ABTS}

\begin{tabular}{lll}
\hline Isolates & Fungi & $\begin{array}{l}\text { Diameter of } \\
\text { decolourized } \\
\text { zones }(\mathbf{m m})\end{array}$ \\
\hline CF-1 & Pleurotus sp. & 6.0 \\
CF-2 & Pleurotus sp. & 5.0 \\
CF-3 & Rhizopus sp. & 1.3 \\
CF-4 & Aspergillus sp. & 0.5 \\
CF-5 & Penicillium sp. & 2.7 \\
CF-6 & Rhizopus sp. & 1.5 \\
CF-7 & Penicillium sp. & 2.9 \\
\hline
\end{tabular}

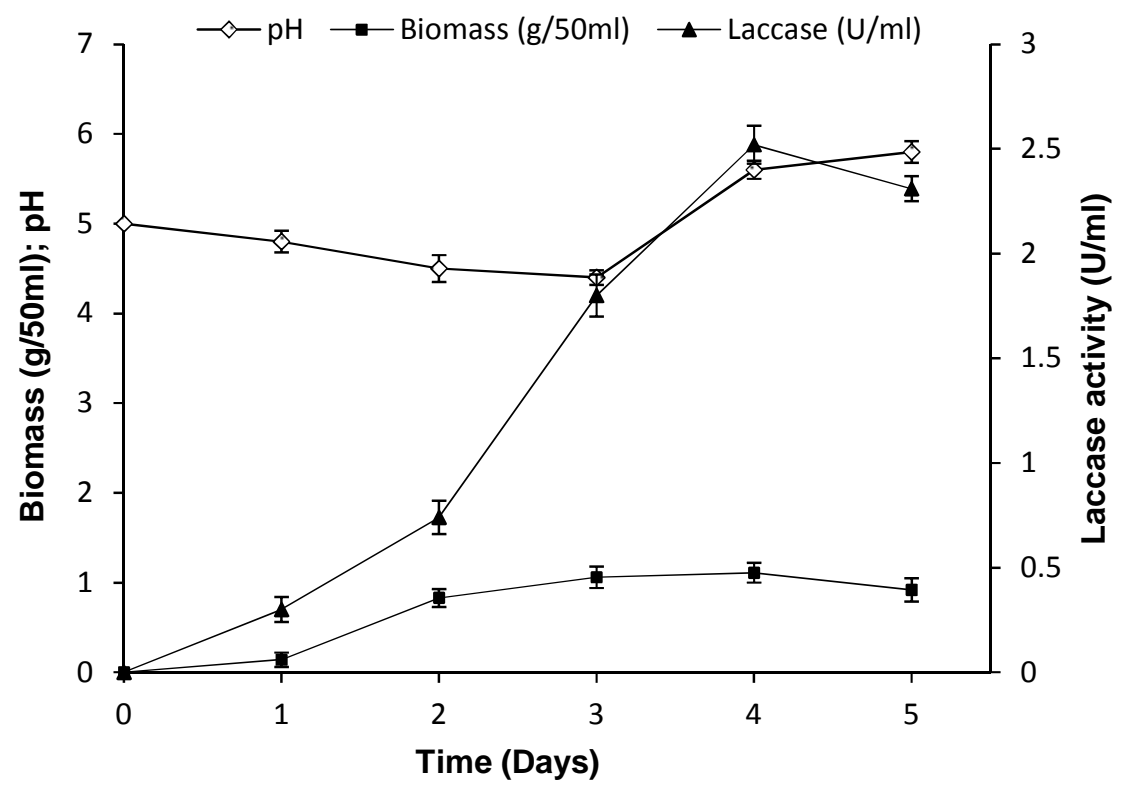

Fig. 1. A 5-day time course study of laccase production with basal medium (unoptimized medium) by $P$. ostreatus 


\subsection{Effect of Carbon Sources on Laccase Production}

A comparison of the effect of some carbon substrates (glucose, glycerol, rice bran and orange peelings) on laccase production was investigated. Fig. 2 shows the effect of carbon sources on laccase production. Maximum laccase production was obtained with orange peelings $(4.60 \mathrm{U} / \mathrm{ml})$ followed by rice bran $(3.9$ $\mathrm{U} / \mathrm{ml}$ ). Glucose showed the least laccase activity $(2.50 \mathrm{U} / \mathrm{ml})$. This result indicates that ground orange peelings had a higher inductive capacity in liquid medium than rice bran, glucose and glycerol. This result also revealed that agricultural waste material used in this study had more stimulatory effect on the production of laccase by the fungus than other sugars and indicated the ability of the fungus to utilize inexpensive and easily available substrate for laccase production. This assertion is in agreement with previous observations that agricultural waste residues are good carbon sources for low cost laccase production [18,21]. According to Osma et al. [28] this is likely related with their contents in water-soluble aromatic compounds (flavones and flavonoids) which is capable of inducing or stimulating the biosynthesis of ligninolytic enzymes. Moreso, the cellulose of orange peelings may have acted as an activator of laccase activity [35]. Patel and Gupte [36] have reported the use of lignocellulosic substrates such as wheat straw as carbon source for the production of laccase. Chen et al. [9] reported the use of bagasse, corncob and sawdust as carbon source to produce laccase from $T$. fusca BCRC 19214. The result of this study is also in agreement with previous reports on $P$. ostreatus where ground mandarin peelings were used to obtain high laccase productivity [28]. Sawdust has been reported as the best carbon source for laccase production by Coriolopsis gallica and Ganoderma lucidum, respectively [18,21]. This result seems very interesting since orange peelings are common agricultural wastes in several countries including Nigeria and implies that their reutilization would help solve pollution problems caused by their inefficient disposal.

Highest biomass yield was observed in the medium containing glucose $(0.53 \mathrm{~g} / 50 \mathrm{ml})$ followed by that containing glycerol $(0.32 \mathrm{~g} / 50$ $\mathrm{ml}$ ) (Fig. 2). The medium containing rice bran showed the least biomass production $(0.185 \mathrm{~g} / 50$ $\mathrm{ml}$ ) within the $96 \mathrm{~h}$ culture period. The result of this investigation showed that the orange peelings and rice brain that had high stimulatory ability for laccase production were poor in supporting the growth of the fungus while glucose encouraged growth but had poor laccase stimulation. D'souza-Ticlo et al. [27] suggests that higher amounts of biomass build-up in the medium containing glucose probably were merely a function of the assimilability of the carbon. This could be justified by the low trend of biomass concentration in the other media containing a little more complex sugar as carbon source.

Fig. 3 shows the effect of orange peelings concentration on laccase production. The result reveals that the medium containing $0.1 \%(\mathrm{w} / \mathrm{v})$ orange peelings exhibited a markedly high laccase activity $(7.44 \mathrm{U} / \mathrm{ml})$ followed by that with $0.3 \%(\mathrm{w} / \mathrm{v})(4.78 \mathrm{U} / \mathrm{ml})$. The least laccase activity was observed in the medium containing $0.7 \%$ $(\mathrm{w} / \mathrm{v})$ orange peelings $(1.96 \mathrm{U} / \mathrm{ml})$. D'souza-Ticlo et al. [27] reported a delay in laccase production in the presence of high concentrations of the carbon source as previously observed in Trametes versicolor. Thus, suggesting that lower concentrations of not-very-easily assimilable carbon sources may overcome the time delay in laccase activity by allowing for constitutive as well as inducible laccase production as incubation time progresses. The result agreed with those previously reported by Osma et al. [28] and Stajic et al. [37]. Hou et al. [38] reported maximum laccase activity with cellobiose as a carbon source after a 12-day static cultivation, noting that the fungus was able to produce laccase on glucose, glycerol, cellulose and starch but with varied activities. Wang et al. [39] reported increased laccase expression from Monotospora $s p$., under carbon-limited cultures and suggested that better enzyme production may be achieved as far as the conditions in which these fungi grow is concerned. However, other previous reports have indicated laccase activity in media with glucose [38] and sucrose [39] as carbon sources. Lee et al. [40], suggests that excessive concentrations of glucose are inhibitory to laccase production in various fungal strains. Also, an excess of sucrose also reduced the production of laccase by blocking its induction and only allowed constitutive production of the enzyme. Use of polymeric substrates like cellulose was able to minimize this problem [41]. 


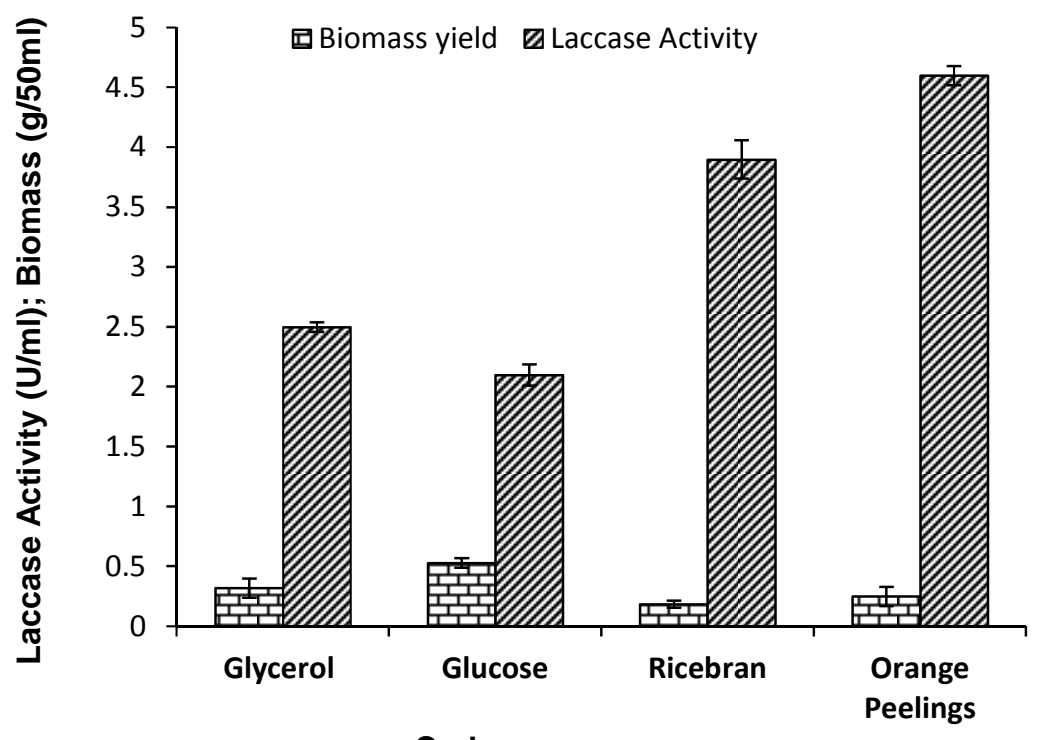

Fig. 2. Effect of different carbon sources on laccase production and biomass yield after $96 \mathrm{~h}$ cultivation

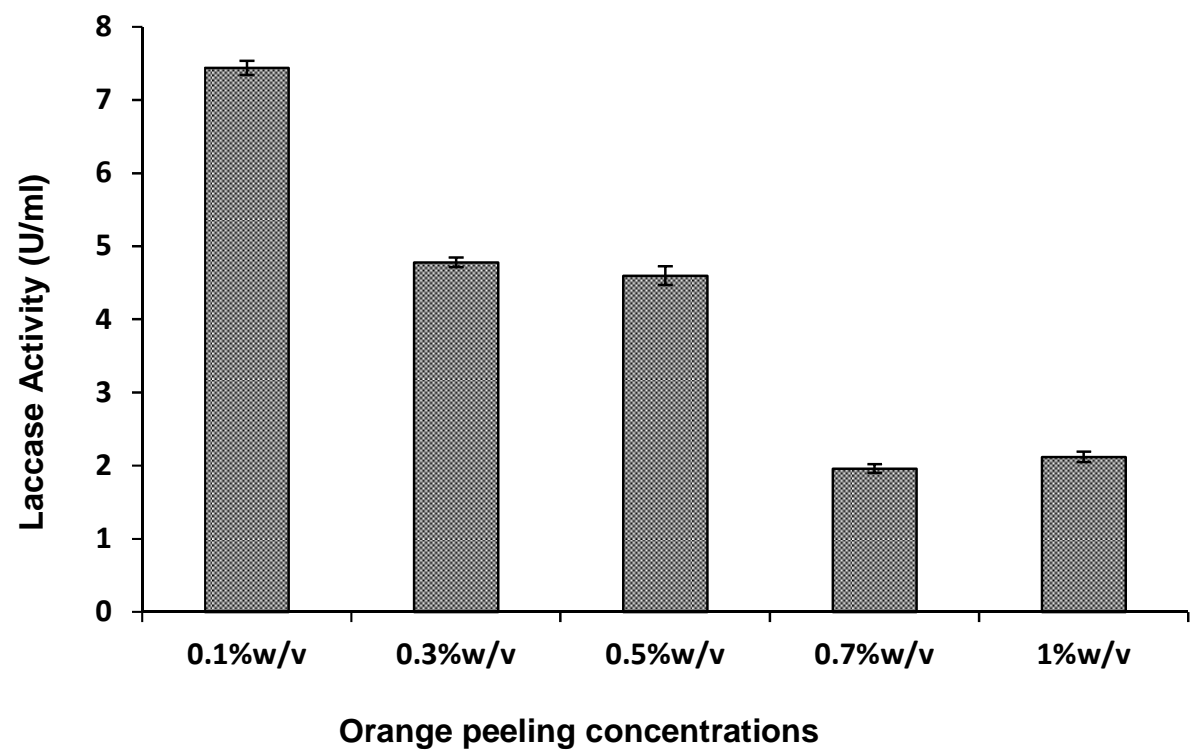

Fig. 3. Effect of orange peeling concentrations $(0.1-1.0 \% \mathrm{w} / \mathrm{v})$ on laccase production after $96 \mathrm{~h}$ cultivation

\subsection{Effect of Nitrogen Sources on Laccase Production}

The influence of various nitrogen sources on laccase production by the fungus was evaluated. The effect of nitrogen sources on laccase production is depicted in Fig. 4. The result indicated that the medium with $\mathrm{NH}_{4} \mathrm{Cl}$ exhibited highest laccase production $(6.95 \mathrm{U} / \mathrm{ml})$ after $96 \mathrm{~h}$. This was followed closely by that containing yeast extract $(6.20 \mathrm{U} / \mathrm{ml})$ while $\mathrm{KNO}_{3}$ had the least laccase production $(1.90 \mathrm{U} / \mathrm{ml})$. Ligninolytic enzyme production has been observed in both nitrogen-sufficient and nitrogen-deficient media using different organisms [36]. However, the influence of nitrogen source on laccase secretion by different microorganisms seems to be controversial [42]. Patel and Gupte [36] observed that the presence of both organic and inorganic nitrogen sources in the medium favoured higher 
laccase production by $T$. giganteum but did not encourage growth. Dong et al. [43] have reported enhanced laccase production in the presence of tryptone and peptone. Yeast extract has been reported to be a suitable nitrogen source for laccase production [44]. Moreso, studies have shown that both the nature and concentration of nitrogen sources are powerful nutrition factors regulating ligninolytic enzyme production by wood-rotting basidiomycetes [34]. Monteiro and De Carvalho [45] had reported high laccase activity with Trametes versicolor using low carbon to nitrogen ratio. However, Buswell et al. [46] reported a higher laccase production at high carbon to nitrogen ratio. Compared to inorganic $\mathrm{N}$ sources, Hou et al. [38], reported increased laccase activity of $P$. ostreatus strain 32, with organic $\mathrm{N}$ sources as the only $\mathrm{N}$ source.

The biomass yield with regard to different nitrogen sources is also presented in Fig. 4. The result revealed that the medium containing yeast extract favoured the highest biomass yield (1.21 $\mathrm{g} / 50 \mathrm{ml})$, followed by peptone $(0.84 \mathrm{~g} / 50 \mathrm{ml})$ whereas at $\mathrm{NH}_{4} \mathrm{Cl}$ gave the least biomass yield $(0.49 \mathrm{~g} / 50 \mathrm{ml})$. It has been suggested that yeast extract and peptone as organic sources may have served as both nitrogen source and as a readily available source of carbon [27].

The result of the effect of different concentrations $(0.1-1.0 \%)$ of the $\mathrm{NH}_{4} \mathrm{Cl}$ on laccase production is presented in Fig. 5. Highest laccase activity (6.50 $\mathrm{U} / \mathrm{ml}$ ) was obtained with a concentration of $0.1 \%$ $(\mathrm{w} / \mathrm{v})$ followed by $0.3 \%(\mathrm{w} / \mathrm{v})(4.61 \mathrm{U} / \mathrm{ml})$ while at a concentration of $1.0 \%(\mathrm{w} / \mathrm{v})$, the least laccase activity $(2.23 \mathrm{U} / \mathrm{ml})$ was observed. Generally, the result showed that increasing the concentrations of $\mathrm{NH}_{4} \mathrm{Cl}$ did not favour laccase production. The influence of $\mathrm{NH}_{4} \mathrm{Cl}$ on biomass yield was negative throughout and its maximum negative impact coincided with maximum laccase production by the 4th day. This might be a synergistic effect of orange peelings and ammonium chloride, indicating that the concentration of nitrogen was critical for laccase production. Shraddha et al. [47] suggested that laccase production is often triggered by nitrogen depletion, although, it was also found that in some strains, nitrogen had no effect on enzyme production. Keyser et al. [48] opined that the low nitrogen content of the synthetic culture or fermentation medium mimics the nitrogen depletion that occurs when the fungus reaches its idiophase, thereby triggering laccase production.

\subsection{Effect of Copper and Manganese lons on Laccase Production}

Result of the effect of copper and manganese ions on laccase production is shown in Fig. 6. This result indicates that the medium supplemented with $\mathrm{Cu}^{2+}$ exhibited a higher laccase production $(6.99 \mathrm{U} / \mathrm{ml})$ than the $\mathrm{Mn}^{2+}$ (3.98 U/ml). According to Wang et al. [49], carbon sources and copper ions are the two most critical factors in improving or stimulating laccase production. Different studies have shown that laccase production is regulated by metal ions such as $\mathrm{Cu}^{2+}$ and $\mathrm{Fe}^{2+}$ by gene expression induction or through translational or posttranslational regulation [50]. Our result is consistent with Patel and Gupte [36] who reported maximum laccase production with copper sulphate. Moreso, Manavalan et al. [51] reported significant increase in laccase production $(1.5 \mathrm{U} / \mathrm{ml})$ by Ganoderma lucidum when the culture was supplemented with $0.4 \mathrm{mM}$ $\mathrm{CuSO}_{4}$. Maximum laccase production $(34.6 \mathrm{U} / \mathrm{ml})$ was obtained when $0.25 \mathrm{mM} \mathrm{CuSO}_{4}$ was added into the medium for Pycnoporus cinnabarimus [52]. According to Passarini et al. [22], Nigrospora sp. CBMAI 1328 produced highest level of laccase $(25.2 \mathrm{U} / \mathrm{L})$ in the presence of 5 $\mu \mathrm{M} \mathrm{CuSO}{ }_{4}$ after $120 \mathrm{~h}$ of incubation. In contrast with our finding, the authors also reported that Arthopyrenia sp. CBMI 1330 presented highest laccase activity without copper sulphate in the medium. The positive effect of $\mathrm{Cu}^{2+}$ addition on the production of laccase by Coriolopsis gallica was reported by Daassi et al. [18].

On biomass yield, manganese ion $\left(\mathrm{Mn}^{2+}\right)$ encouraged more fungal growth $(1.81 \mathrm{~g} / 50 \mathrm{ml})$ than the copper ion $\left(\mathrm{cu}^{2+}\right)(1.32 \mathrm{~g} / 50 \mathrm{ml})$ after a $96 \mathrm{~h}$ of incubation. D'souza-Ticlo et al. [27] opined that $\mathrm{cu}^{2+}$ can have a negative coefficient with other media components on biomass accumulation. Our result is in contrast with the work of Passarini et al. [22] who reported high biomass production in the presence of copper sulphate for Nigrospora sp. CBMAI 1328. Copper ion as a micronutrient has a key role as a metal activator; induces laccase transcription; and plays an important role in laccase production [53]. Overall, laccase production is reported to be induced in the presence of $\mathrm{Cu}^{2+}$ [54]. A possible explanation for this stimulatory effect of copper on laccase biosynthesis could be a role for the enzyme activity in terms of a defense mechanism against oxidative stress, with laccase involved in the synthesis of pigments to prevent the uptake of metals [55]. Furthermore, the promoter regions 
of laccase genes have been shown to contain various recognition sites specific for heavy metals which when bond to, induce laccase production [56].

Furthermore, various concentrations of copper in the range of $0.01-0.1 \%(\mathrm{w} / \mathrm{v})$ were studied. Fig. 7 shows the effect of copper ion concentration on laccase production. Maximum production of laccase $(9.33 \mathrm{U} / \mathrm{ml})$ was obtained at $0.05 \%(\mathrm{w} / \mathrm{v})$ copper concentration. Further increment of copper concentrations beyond $0.05 \% \quad(\mathrm{w} / \mathrm{v})$ resulted in corresponding decrease in laccase production. Passarini et al. [22] and Liu et al. [25] opined that $\mathrm{cu}^{2+}$ requirements by microorganisms are usually satisfied by very low concentrations of $1-10 \mu \mathrm{M}$ but toxic to fungal metabolism at higher concentrations. The trend of our result on effect of copper concentration on laccase production may be because of insinuation that higher concentration of copper is inhibitory to fungal growth [44]. Similar result has been reported from Tricholoma giganteum [36]. Our result is consistent with Manavalan et al. [51] and Mann et al. [57] who reported that inclusion of 0.75 and $0.4 \mathrm{mM}$ copper significantly induced laccase production in Cerrena consors and Ganoderma lucidum, respectively.

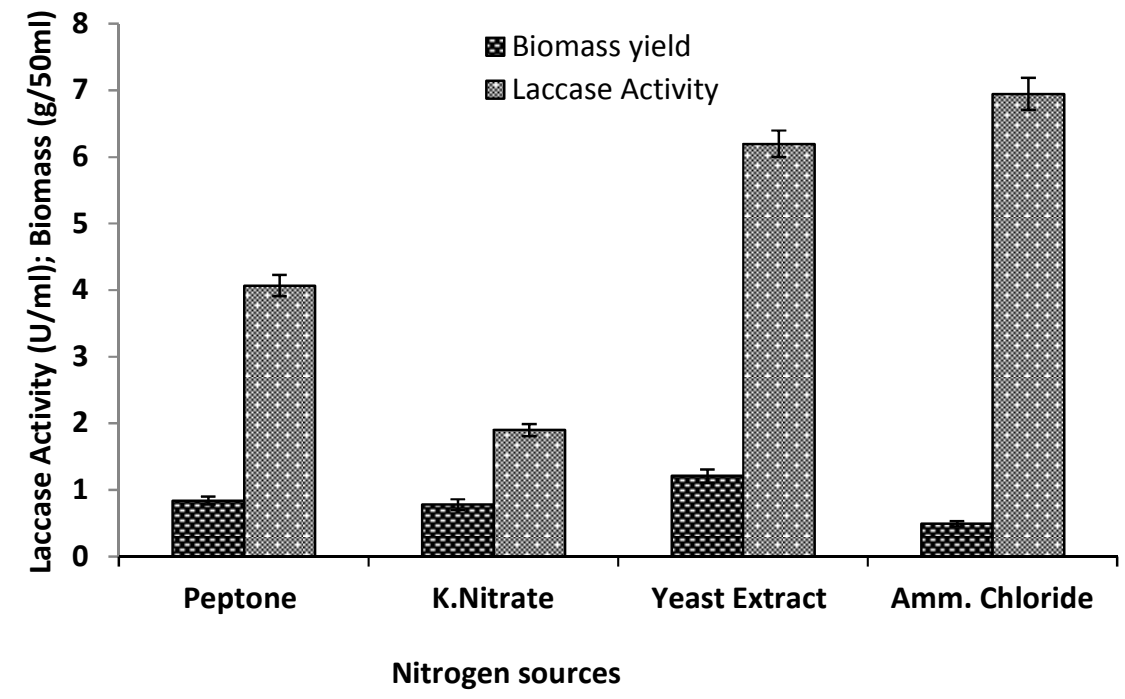

Fig. 4. Effect of different nitrogen sources on laccase production and biomass yield after $96 \mathrm{~h}$ cultivation

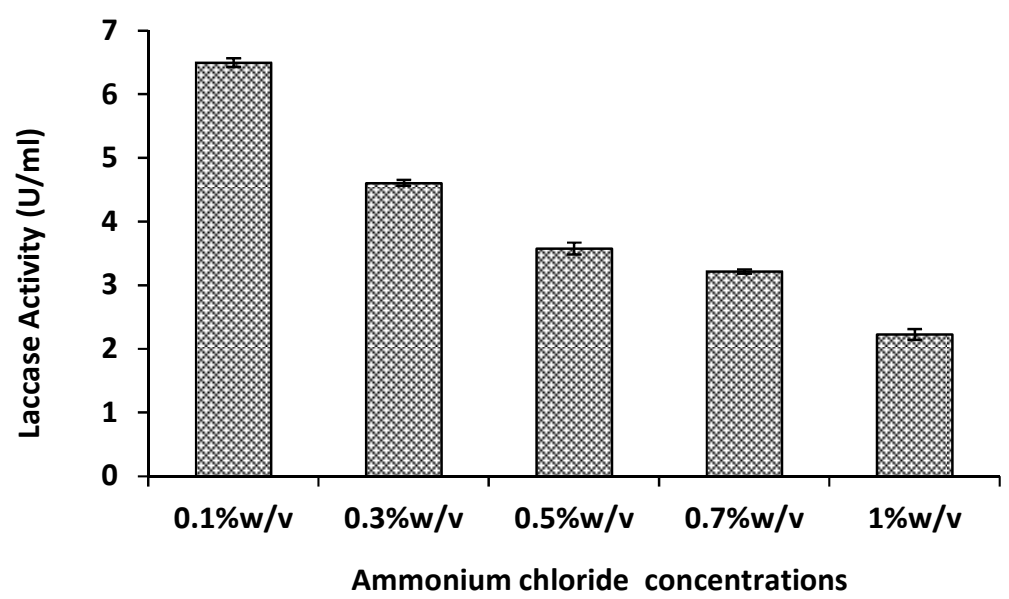

Fig. 5. Effect of ammonium chloride concentrations (0.1 $1.0 \% \mathrm{w} / \mathrm{v}$ ) on laccase production 


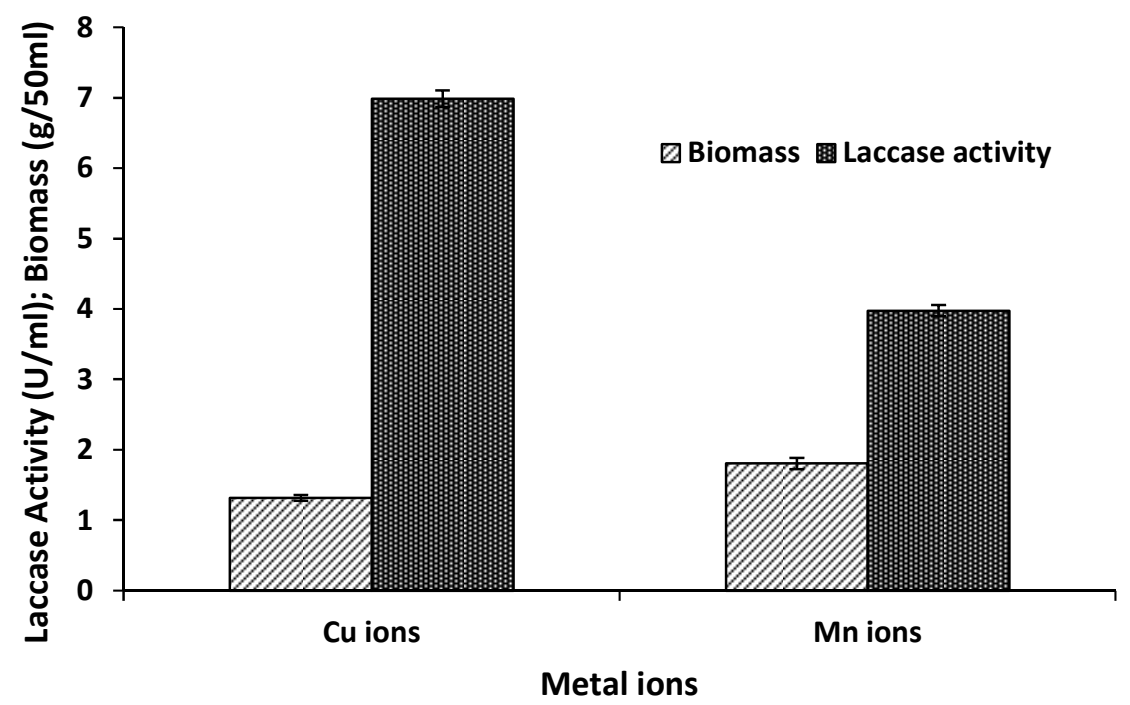

Fig. 6. Effect of metal ions on laccase production and biomass yield after $96 \mathrm{~h}$ cultivation

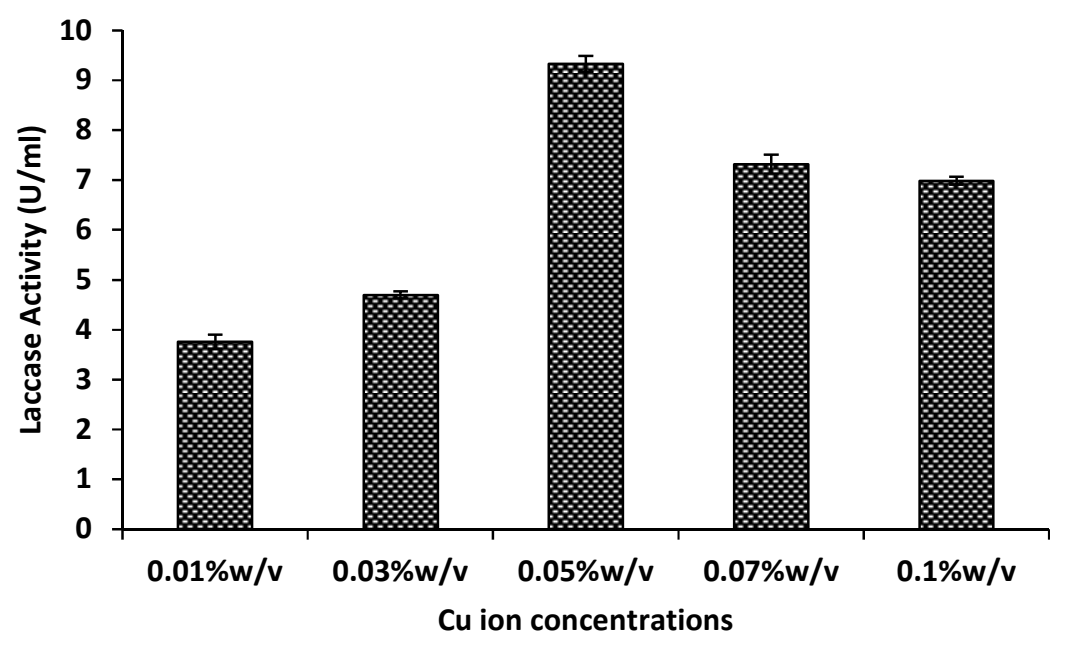

Fig. 7. Effect of $\mathrm{Cu}$ ion concentrations $(0.01-0.1 \% \mathrm{w} / \mathrm{v})$ on laccase production after $96 \mathrm{~h}$ cultivation

The role of copper in the enhancement of laccase activity has been well demonstrated in both fungi and bacteria [58,59]. However, Chen et al. [9] reported contrary results from Thermobifida fusca as well as a reduced laccase activity by metal ions of $\mathrm{Hg}$, and is similar with the results from Streptomyces psammoticus [60], Trametes hirsute [61] and Paraconiothyrium variabile [62]. In an orthogonal matrix study showing effects of copper with a new strain of white rot fungus $W R-1$ isolated from tree bark, laccase production was considerably enhanced to $410 \mathrm{U} / \mathrm{ml}$ by incorporation of 0.5 to $1 \mathrm{mM}$ copper in the optimized medium [44]. According to the report a significant reduction in cell growth with substantial decrease in laccase activity was observed at $2 \mathrm{mM}$ concentration of copper. Infact, further increase of copper to $5 \mathrm{mM}$ led to almost negligible cell growth and very small laccase activity. Dhakar and Pandey [63] also reported a 2-fold increase in laccase production with maximum being at $0.4 \mathrm{mM}$ concentration and further increment in $\mathrm{CuSO}_{4}$ (up to $1.0 \mathrm{mM}$ ) resulted in decline of laccase production. $\mathrm{CuSO}_{4}$ 
is a constituent of the catalytic centre of the laccase; hence it is important for the synthesis of the respective enzyme [64].

In addition, reports suggest that the effect of $\mathrm{Cu}^{2+}$ on laccase production might be related to transcriptional regulation of laccase genes, as well as positive adjustment of laccase activity and stability [29]. In this present study, the media containing $\mathrm{Cu}^{2+}$ concentrations beyond $0.05 \%(w / v)$ showed a significant decrease in laccase production and fungal growth. This may be attributed to the inhibitory effect of $\mathrm{Cu}^{2+}$ at higher concentrations as equally observed by Passarini et al. [22]. Our result is in agreement with the reports of Galhaup et al. [34] and Stajic et al. [37] who separately reported that the addition of $\mathrm{CuSO}_{4}$ in various concentrations (1-10 mM) stimulated laccase production in $T$. pubescens, $P$. ostreatus HA1493, $P$. ostreatus HA1494 and $P$. eryngii. Cordi et al. [29] observed that the inclusion of 0.007-0.1 mM copper sulphate during into the growth medium of Trametes versicolor enhanced high laccase activity. This result showed that the addition of $\mathrm{CuSO}_{4}$ at very low concentrations favours production of laccase by $P$. ostreatus but slows biomass accumulation. Thurston [1] affirmed that metals are required by fungi for their normal growth and laccase biosynthesis. According to the author, one molecule of laccase requires four copper atoms for its full function.

\subsection{Effect of Inducer Compounds on Laccase Production}

Laccase production has been found to be highly dependent on the conditions for cultivation and nutritive media composition $[65,66]$. In this study, addition of these supplements to the media improved laccase production in varying degrees. Zheng and Obbard [67], opined that these inducers, being surfactants especially Tween 80 , can increase the bioavailability of less soluble substrates for the fungi and stimulate the growth of the fungal spores. The effect of inducer compounds on laccase production is shown in Fig. 8. Soya oil exhibited a markedly higher laccase activity $(5.89 \mathrm{U} / \mathrm{ml})$ followed by Tween 80. ABTS showed the least laccase activity (1.64 $\mathrm{U} / \mathrm{ml}$ ) within the incubation period. This result is in agreement with Osma et al. [28] who observed the influences of ABTS, Tween 20, soya oil, and Malachite green on laccase production, with soya oil yielding a markedly high laccase activity than the other inducers. Interestingly, the above- mentioned compounds are non-toxic contrary to those commonly used to stimulate laccase synthesis [44]. Patel and Gupte [36] also reported the increase in yield of laccase after the addition of Tween 80. Similar results have been reported in other studies $[68,69]$. Soya oil promoted highest biomass yield $(1.11 \mathrm{~g} / 50 \mathrm{ml})$ followed by Tween $80(0.98 \mathrm{~g} / 50 \mathrm{ml})$. The least biomass was observed in the medium with ABTS $(0.72 \mathrm{~g} / 50 \mathrm{ml})$. Reports suggest that the positive impact of soya oil on enzyme production may be due to its surfactant property which emulsifies the fungal membrane thereby aiding the release of cell membrane-associated laccases as well as in the secretion of the normal extracellular laccases [70].

The effect of various concentrations of soya oil on laccase secretion is depicted in Fig. 9. The different concentrations elicited varied levels of laccase secretion. Maximum laccase production was obtained at $0.5 \%(\mathrm{v} / \mathrm{v})$ soya oil concentration after which further increase in soya oil concentration led to decrease in laccase production. The lowest laccase production was noticed at $0.1 \%(\mathrm{v} / \mathrm{v})$. Liu et al. [25] suggested an antagonistic effect of inducers on $\mathrm{CuSO}_{4}$ by reducing laccase production. According to the report, the reason is not clear, but may be due to the poisoning of these inducers for cell growth as well as laccase production under selected concentrations. Cserhati [70] suggested that the role of soya oil may be due to either of the following reasons or a combination thereof; (a) The surfactant property of soya oil which emulsifies the fungal membrane aiding in the release of cell membrane-associated laccases as well as in the secretion of the normal extracellular laccases. (b) The decrease in amount of evaporation of moisture due to the presence of soya oil, which would otherwise have led to the concentration of medium components during prolonged incubation periods and thus, either increase adverse interactions between compounds or the precipitation of critical components. Wang et al. [39] opined that surfactants increase the activity of the already secreted enzyme, although the specific mechanism by which they enhance extracellular enzyme production in filamentous fungi has not been elucidated.

\subsection{Effect of Initial pH on Laccase Production}

The hydrogen ion concentration $(\mathrm{pH})$ is one of the important parameters in fungal cultivation 
and tolerance to a wider range is indicative of the ecological resilience possessed by the fungus [63]. The optimum $\mathrm{pH}$ value for laccase production varies depending on the substrates employed, although many reports have suggested a bell-shaped profile for laccase activity [47]. The optimal activity is mainly obtained in the $\mathrm{pH}$ range of 3.0-5.0 [36]. The effect of $\mathrm{pH}$ of the culture medium was varied from 4.0 to 8.0. In this present study, the maximal laccase production was obtained at $\mathrm{pH}$ $4.5(7.09 \mathrm{U} / \mathrm{ml})$ (Fig. 10). However, further rise in $\mathrm{pH}$ showed no increase in the production of the laccase. This may be attributed to the poor mycelial growth at an increased $\mathrm{pH}$ which may hinder laccase production. Similar result has been reported by Diaz et al. [71] with maximum enzyme production at $\mathrm{pH}$ 4.5. Our result is consistent with the reports of Strong et al. [72] and Patel et al. [3] with optimum laccase production at $\mathrm{pH}$ 4.5. The result obtained in the current study differs with the observation of Janusz et al. [73] who reported $\mathrm{pH} 7.5$ as optimum for laccase production by Rhizoctonia praticola. Our result is also at variance with $\mathrm{pH} 3$ reported by Kocyigit et al. [74] as the optimum $\mathrm{pH}$ for laccase production from Tramete strogii. The optimum $\mathrm{pH}$ for L1 (isozyme of laccase) was 4.0 whereas the optimum pH for L2 was 5.0. Laccases extracted from Trametes versicolor by Han et al. [75] showed high enzyme activity at a broad $\mathrm{pH}$ range with the optimal being 3.0. Contrary results have been reported by Patel and Gupte [36] and Ravikumar et al. [76] with maximum enzyme production at $\mathrm{pH}$ 5.0. In a recent work by Daassi et al. [18], maximum laccase production by Coriolopsis gallica was obtained at $\mathrm{pH}$ 5.0. In addition, Chhaya and Gupte [77] reported maximum laccase production at $\mathrm{pH} 5.0$ using one-factor-at-a-time methodology under solid state fermentation. However, most studies show that $\mathrm{pH}$ between 4.5 and 6.0 is suitable for enzyme production $[1,78,79]$. Maximum growth of the fungus coincidentally was obtained at $\mathrm{pH} 4.5(1.04 \mathrm{~g} / 50$ $\mathrm{ml}$ ) when the maximum enzyme was achieved, followed by $\mathrm{pH} 4.0(0.83 \mathrm{~g} / 50 \mathrm{ml})$ as shown in Fig. 10. The alkaline $\mathrm{pH} 8.0$ showed the least biomass production $(0.33 \mathrm{~g} / 50 \mathrm{ml})$. The difference in redox potential between the phenolic substrate and the $\mathrm{T} 1 \mathrm{Cu}$ could increase oxidation of the substrate at high $\mathrm{pH}$ values, while the $\mathrm{OH}$ - binds to the T2/T3 tri-nuclear $\mathrm{Cu}$ centre. These opposing effects can assist in determining the optimal $\mathrm{pH}$ for laccase secretion [8].

\subsection{Time Course Study of Laccase Production Using the Various Organic and Inorganic Feed Substrates}

Laccase production has been reported to be influenced by culture conditions such as initial $\mathrm{pH}$, metal ion, inducer compound, the carbon and nitrogen sources [80]. Time course study of laccase production by $P$. ostreatus was conducted before and after the medium optimization under static submerged fermentation. Thus, the culture conditions for the production of laccase using optimized physical and chemical parameters were investigated. The result of the time course study for laccase production using optimized medium parameters by the fungus is presented in Fig. 11. The appearance of laccase activity in the culture broth became significant after $24 \mathrm{~h}$ of cultivation and continued to increase with increase in cultivation time. The production of laccase peaked at the late stage of cultivation and this observation shows that the secreted enzyme was a secondary metabolite instead of primary metabolite. Laccase production was remarkably low in the medium for the first 3 days $(1.23 \mathrm{U} / \mathrm{ml})$ after which a steady increase was observed. Laccase activity in the optimized medium increased 3.0 fold compared to that of unoptimized medium $(2.5 \mathrm{U} / \mathrm{ml})$ with maximum laccase activity of $7.21 \mathrm{U} / \mathrm{ml}$ and $1.77 \mathrm{~g} / 50 \mathrm{ml}$ of fungal biomass on the 7th day of incubation. However, the laccase activity decreased after further cultivation time. This suggests an alteration to secondary metabolism and agreed with reports by Galhaup et al. [34], Patel et al. [3] and Liu et al. [25] on P. ostreatus and different fungi, respectively. The finding of this study differed with other previous reports on other fungi such as Phlebia floridensis, 20th day [81], Pleurotus fossulatus, 15th day [19] and Monotospora sp., 8th day [39]. Cilerdzic et al. [21] obtained maximum laccase production by Ganoderma lucidum on the 14th day of cultivation under submerged condition. Shankar and Shikha [82] reported 2.49-fold higher laccase production under optimized condition by Peniophoro sp. Laccase production by Coriolopsis gallica under solid state fermentation was enhanced 3.2 times using RSM optimization [18]. Patel and Gupte [36] also reported 3.02-fold higher laccase production using optimized medium by Tricholoma gigantum. The maximum laccase activity obtained in the present study is higher than the maximum laccase activity of 4.96 $\mathrm{U} / \mathrm{ml}$ for Thermobifida fusca using bagasse as carbon source [9]. 


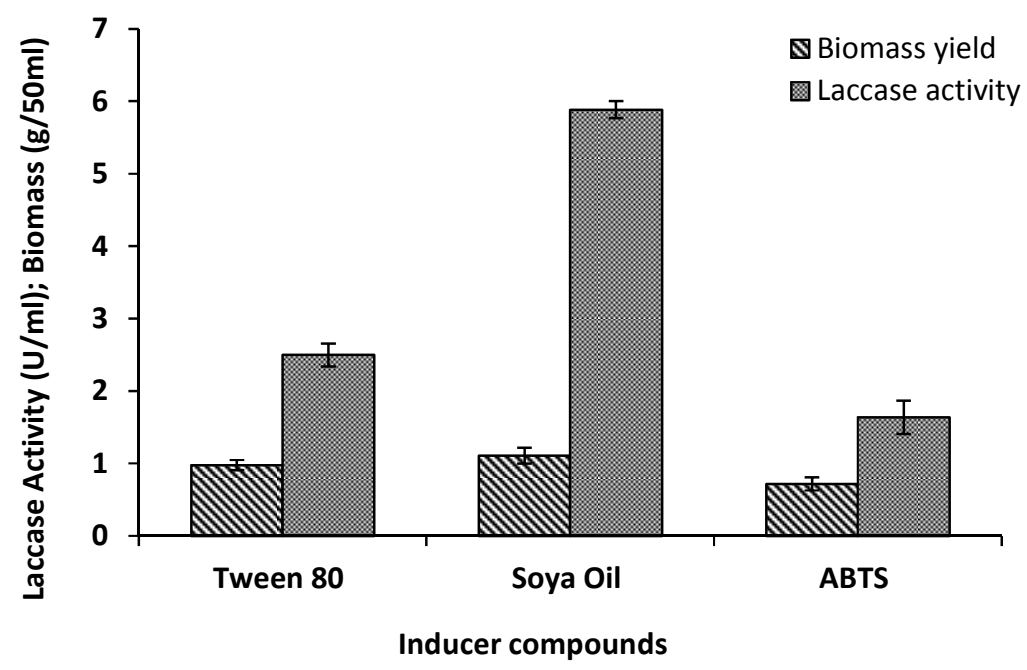

Fig. 8. Effect of $\mathrm{Cu}$ ion concentrations $(0.01-0.1 \% \mathrm{w} / \mathrm{v})$ on laccase production after $96 \mathrm{~h}$ cultivation

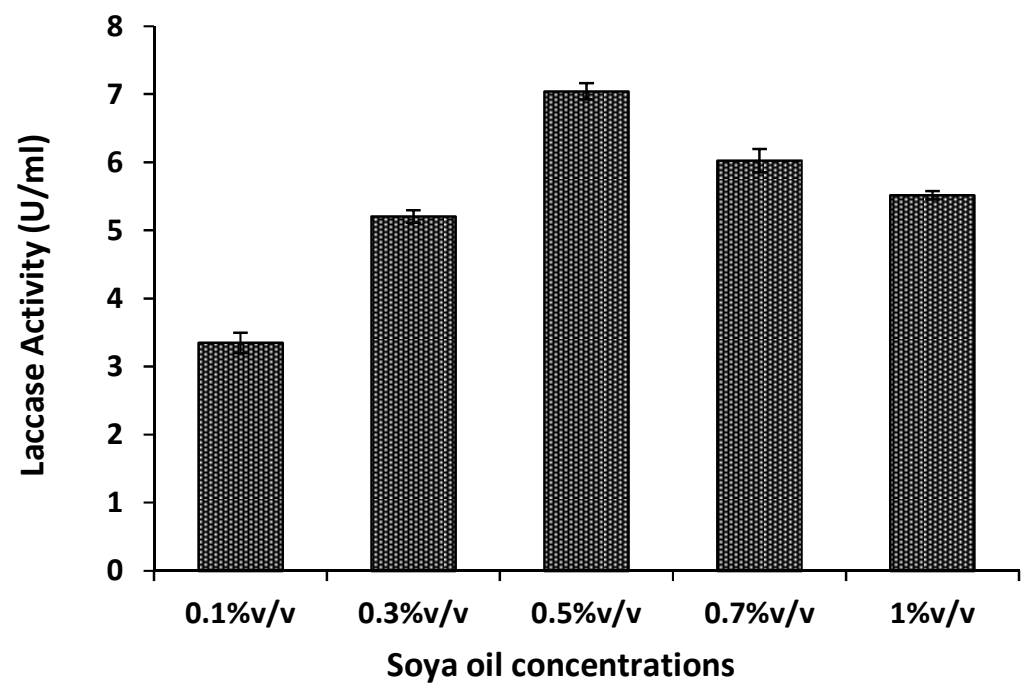

Fig. 9. Effect of soya oil concentrations $(0.1-1.0 \% \mathrm{v} / \mathrm{v})$ on laccase production after $96 \mathrm{~h}$ cultivation

Fungal biomass increased remarkably after $72 \mathrm{~h}$ incubation (1.34 g/50 ml), coinciding with continuous decrease in medium $\mathrm{pH}$ (4.2), a probable indication of the formation of organic acids by primary metabolism of $P$. ostreatus. This low $\mathrm{pH}$ encouraged maximum biomass (2.38 $\mathrm{g} / 50 \mathrm{ml}$ ) before a steady $\mathrm{pH}$ increase from the 5 th day (4.8) to the 9th day (8.6). This result indicated that maximum production of enzyme and biomass was obtained on the 7th day and 5th day, respectively. Patel and Gupte [36] reported that maximum production of laccase and biomass were both obtained on the 16th day of fermentation. Increase in fungal laccase and biomass yield was observed from $\mathrm{pH} 4.0$ to 6.9, but was reduced with further increase in $\mathrm{pH}$. The maximum laccase activity of $7.21 \mathrm{U} / \mathrm{ml}$ and mycelial biomass of $1.77 \mathrm{~g} / 50 \mathrm{ml}$ was observed at $\mathrm{pH}$ 6.9. Such a phenomenon may be explained by the probable turn off of a large number of genes and a change in enzymerelated synthesis in the presence of increasing $\mathrm{pH}$ values [83]. Previous studies have suggested that the expression of laccases by most white rot fungi required an acidic initial $\mathrm{pH}, \mathrm{N}$-limitation and higher $\mathrm{C} / \mathrm{N}$ ratio in cultures $[84,85]$. Wang et al. [39] reported that enzyme production was achieved with $P$. fossulatus in $\mathrm{N}$-rich and $\mathrm{C}$ limitation cultures at an alkaline $\mathrm{pH}$. 


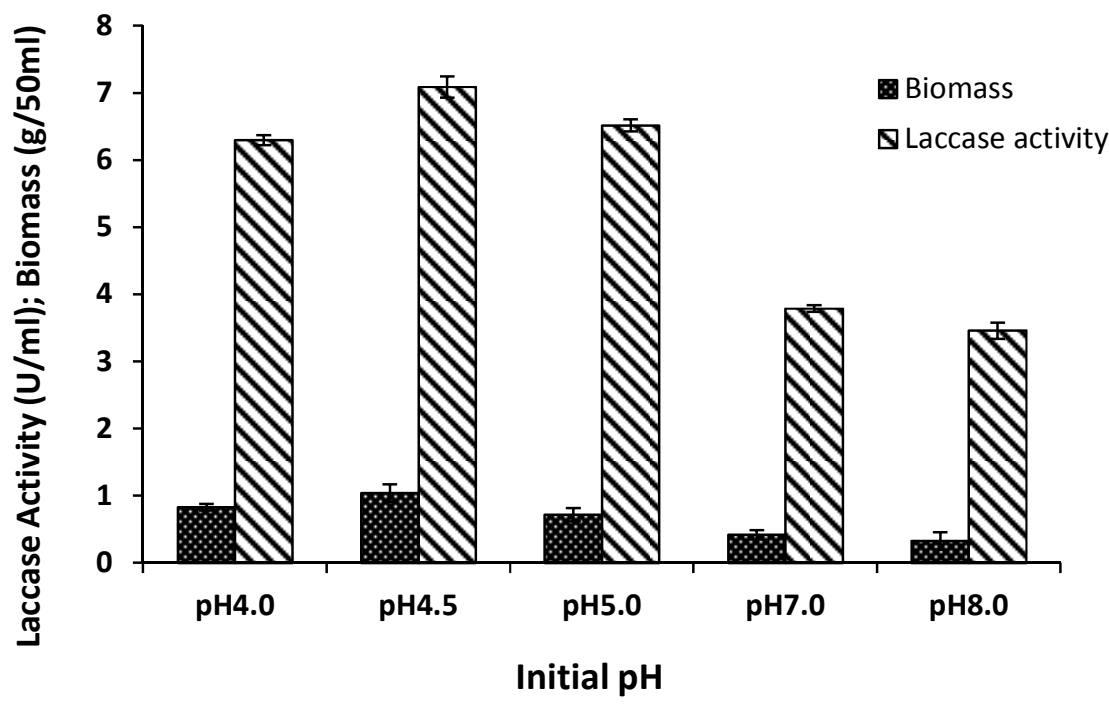

Fig. 10. Effect of different initial pH on laccase production and biomass yield after $96 \mathrm{~h}$ cultivation

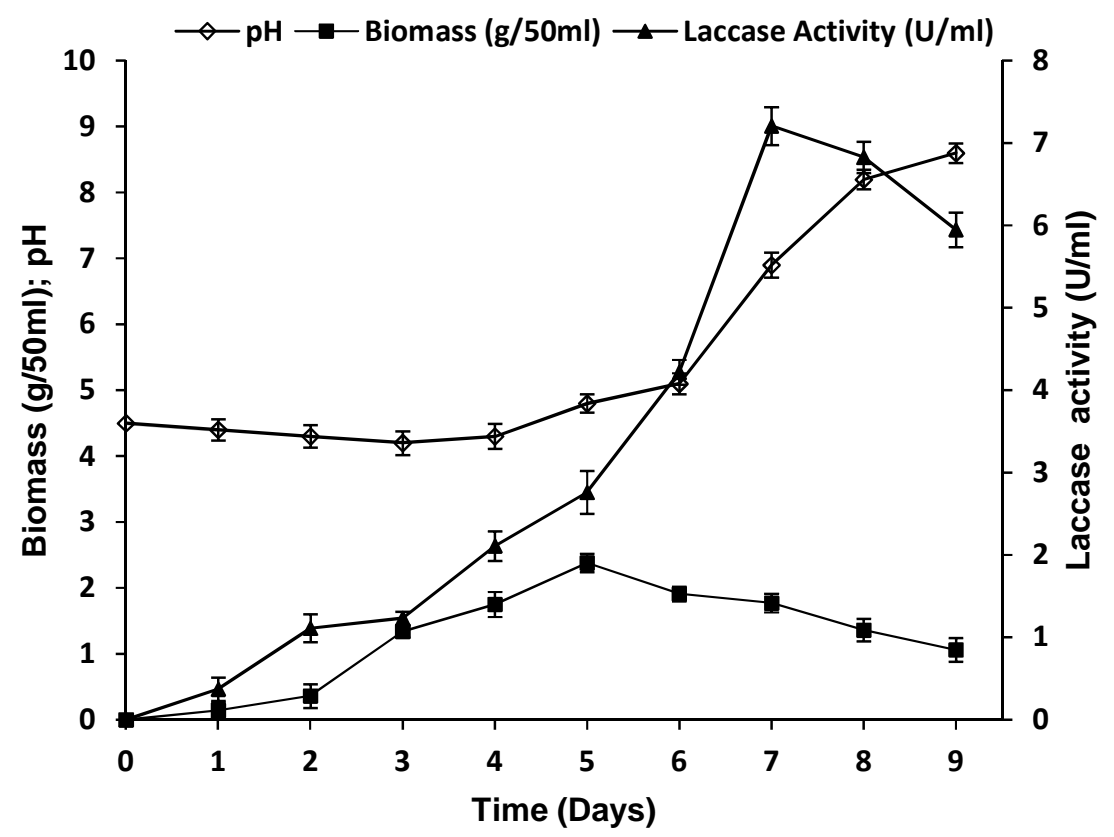

Fig. 11. A 9-day time course study of laccase production with optimized medium by $P$. ostreatus

\section{CONCLUSION}

This study revealed that interesting novel laccase producers can be still discovered from our local environments by very simple plate test methods, and also demonstrated the convenience of using Malt Extract Agar (MEA) as a screening medium.
The current study has shown the potential of $P$. ostreatus to produce laccase under static submerged fermentation. In addition, this study confirms and assesses the application of lignocellulosic substrates as cost effective and easily available solid substrates. The optimal conditions obtained were $\mathrm{pH} 4.5$, soya oil $0.5 \%$, 
$\mathrm{CuSO}_{4} \quad 0.5 \%, \mathrm{NH}_{4} \mathrm{Cl} 0.1 \%$ and ground orange peelings $0.1 \%$. However, the overall optimization of all the culture conditions increased laccase activity $(7.21 \mathrm{U} / \mathrm{ml})$ by 3-fold compared to unoptimized basal medium $(2.5 \mathrm{U} / \mathrm{ml})$ under static SmF using orange peelings as a lignocellulosic substrate. To the best of our knowledge, this is the first report on laccase production by this fungus using orange peelings under static SmF. The results obtained in this present study reveals that the laccase-producing potential of the local fungal strain $P$. ostreatus can be enhanced by optimizing the cultural conditions with safe and cost effective substrates. This study therefore, has found its relevance not only in the re-utilization of such agro industrial wastes (lignocellulosic substrates) for the production of laccase but also in alleviating pollution problems caused by their improper disposal. Moreso, this fungus can be further explored as a prospective candidate for the large scale laccase production for its various bioprocessing and industrial applications. Attempts to conduct molecular identification of the fungus and construct phylogenetic tree as well as efforts to purify and characterize the enzyme are currently on-going in our laboratory.

\section{COMPETING INTERESTS}

Authors have declared that no competing interests exist.

\section{REFERENCES}

1. Thurston CF. The structure and function of fungal laccases. Microbiology. 1994;140: 19-26.

2. Shleev S, Reimann CT, Serezhenkov V, Burbaev D, Yaropolov Al, Gordon L, Ruzgas T. Autoreduction and aggregation of fungal laccase in soluting phase: Possible correlation with resting form of laccase. Biochimie. 2006;88:1275-1285.

3. Patel H, Gupte A, Gupte S. Effect of different culture conditions and inducers on production of laccase by a basidiomycete fungal isolate Pleurotus ostreatus HP-1 under solid state fermentation. BioResources. 2009;4:268-284.

4. Xu F. Recent progress in laccase study: Properties, enzymology, production and applications. Encyclopaedia of Bioprocessing Technology, Fermentation, Biocatalysis and Bioseparation. New York: John Wiley and Sons. 1999;264-281.
5. Alcalde $\mathrm{M}$, Bulter $\mathrm{T}$, Arnold $\mathrm{FH}$. Colorimetric assays for biodegradation of polycyclic aromatic hydrocarbons by fungal laccases. J Biomol Screening. 2002;7:547553.

6. Yaropolov AI, Skorobogat'ko OV, Vartanov SS, Vartolomeyer SD. Laccase: Properties, catalytic mechanism and applicability. Appl Biochem Biotechnol. 1994;49:257-280.

7. Nyanhongo GS, Gomesa J, Gubitze GM, Zvauyab R, Read JS, Steinera W. Decolorization of textile dyes by laccase from a newly isolated strain of Trametes modesta. Water Research. 2002;36:14491456.

8. Kunamneni A, Ballesteros A, Plou FJ, Alcalde M. Fungal laccase - A versatile enzyme for biotechnological applications. Communicating Current Research and Educational Topics and Trends in Applied Microbiology. Formatex Ed. 2007;233-245.

9. Chen CY, Huang YC, Wei CM, Meng M, Liu WH, Yang $\mathrm{CH}$. Properties of the newly isolated extracellular thermo-alkali-stable laccase from thermophilic actinomycetes, Thermobifida fusca and its application in dye intermediates oxidation. AMB Express. 2013;3:49.

10. Bustamante M, Gonzalez ME, Cartes A. Effect of soya lecithin on the enzymatic system of the white-rot fungi Anthracophyllum discolor. J. Ind. Microbiol. Biotechnol. 2010;38:189-197.

11. Eugenio ME, Carbajo JM, Martín JA, González AE, Villar JC. Laccase production by Pycnoporus sanguineus under different culture conditions. Journal of Basic Microbiology. 2009;49(5):433440.

12. Sadhasivam S, Savitha S, Swaminathan $\mathrm{K}$, Lin FH. Production, purification and characterization of mid-redox potential laccase from a newly isolated Trichoderma harzianum WL1. Process Biochem. 2008;43:736-742.

13. Birhanli E, Erdogan S, Yesilada O, Onal Y. Laccase production by newly isolated white rot fungus Funalia trogii: Effect of immobilization matrix on laccase production. Biochem Eng J. 2013;71:134139.

14. Mishra A, Kumar S, Pandey AK. Laccase production and simultaneous decolourization of synthetic dyes in unique inexpensive medium by new isolates of 
white rot fungus. Int Biodet Biodeg. 2011;65:487-493.

15. Savithat SD, Gururaj BT, Nityanand C, Anup AC, Gouri D, Azhar MBP. Isolation of laccase producing fungi and partial characterization of laccase. Biotechnol. Bioinf. Bioeng. 2011;1:543-549.

16. Buddolla V, Subhosh M, Chandra, Pallavi $H$. Screening and assessment of laccase producing fungi isolated from different environmental samples. Afr. J. Biotechnol. 2008;7:1129-1133.

17. Lettera V, Piscitelli A, Leo G, Pezzella C, Giovanni Sannia G. Identification of a new member of Pleurotus ostreatus laccase family from mature fruiting body. Fungal Biol. 2010;114(9):724-730.

18. Daassi D, Zouari-Mechichi H, Frikha F, Rodriguez-Couto S, Nasri M, Mechichi T. Sawdust waste as a low-cost supportsubstrate for laccase production and absorbent for azo dyes decolorization. J. Environmental Health Science \& Engineering. 2016;14:1-12.

19. Chowdhury P, Hari B, Chakraborty B, Mandal B, Naskar S, Nirmalendu D. Isolation, culture optimization and physicochemical characterization of laccase enzyme from Pleurotus ostreatus. Pakistan J Biol Sci. 2014;17:173-181.

20. Chawachart N, Khanongnuch C, Lumyong $\mathrm{S}$, Watanabe T. Ricebran as an efficient substrate for laccase production from thermotolerant basidiomycete Coriolus versicolor RC3. Fungal Diversity. 2004;15:23-32.

21. Ćilerdžić J, Stajić M, Vukojević J, Lonćar N. Intraspecific diversity in the production and characterization of laccase within Ganoderma lucidum. BioResources. 2014; 9(3):5577-5587.

22. Passarini MRZ, Ottoni CA, Santos C, Lima $\mathrm{N}$, Sette LD. Induction, expression and characterisation of laccase genes from the marine-derived fungal strains Nigrospora sp. CBMAI 1328 and Arthopyrenia sp. CBMAI 1330. AMB Express. 2015;5:19.

23. Gochev VK, Krastanov Al. Isolation of laccase-producing Trichoderma sp. Bulgarian J Agric Sci. 2007;13:171-176.

24. Viswanath $B$, Chandra MS, Pallavi $H$, Reddy BR. Screening and assessment of laccase producing fungi isolated from different environmental samples. African $\mathrm{J}$ Biotechnol. 2008;7:1129-113.

25. Liu Z, Zhang D, Hua Z, Li J, Du G, Chen J. A newly isolated Paecilomyces sp. WSH-
L07 for laccase production: Isolation, identification and production enhancement by complex inducement. J Ind Microb Biotechnol. 2009;36:1315-1321.

26. Samuels GJ, Chaverri P, Farr DF, McCray EB. Trichoderma online. Systematic Botany and Mycology Lab., ARS, USA; 2006.

27. D'Souza-Ticlo D, Garg S, Raghukumar C. Effects and interactions of medium components on laccase from a marinederived fungus using response surface methodology. Marine Drugs. 2009;7:672688.

28. Osma JF, Saravia V, Toca-Herrera JL, Couto SR. Mandarin peelings: The best carbon source to produce laccase by static cultures of Trametes pubescens. Chemosphere. 2007;67:1677-1680.

29. Cordi L, Minussi RC, Freire RS, Duran N. Fungal laccase: Copper induction, semipurification, immobilization, phenolic effluent treatment and electrochemical measurement. African J Biotechnol. 2007; 6:1255-1259.

30. Aneja MK, Sharma S, Fleischmann F, Stich S, Heller W, Bahnweg G, Munch JC, Schloter M. Microbial colonization of beech and spruce litter-influence of decomposition site and plant litter species on the diversity of microbial community. Microb Ecol. 2006;52:127-135.

31. Thiyam B, Sharma GD. Isolation and identification of fungi associated with local fruits of Barak Valley, Assam. Current World Environment. 2013;8(2):319-322.

32. Mc Lean RC, Ivimey-Cook WR. Plant Science formule. Macmillian \& Co. Ltd, New York; 1965.

33. Kiiskinen LL, Ratto M, Kruus K. Screening for novel laccase producing microbes. J Appl Microbiol. 2004;97:640-646.

34. Galhaup C, Wagner H, Hinterstoisser B, Haltrich D. Increased production of laccase by the wood-degrading basidiomycete Trametes pubescens. Enzyme Microb Technol. 2002;30:529-536.

35. Srinivan C, D'Souza TM, Brominatham K, Reddy CA. A demonstration of laccase in the white-rot basidiomycete Phanerochaete chrysosporium. Appl Environ Microbiol. 1995;61:4274-4277.

36. Patel H, Gupte A. Optimization of different culture conditions for enhanced laccase production and its purification from Tricholoma giganteum AGHP. 
Bioresources and Bioprocessing. 2016;3: 11.

37. Stajic M, Persky L, Hadar Y, Friesem D, Duletic-lausevic S, Wasser SP, Nevo E. Effect of copper and manganese ions on activities of laccase and peroxidases in three Pleurotus species grown on agricultural wastes. Appl Biochem Biotechnol. 2006;168:87-96.

38. Hou H, Zhou J, Wang J, Du C, Yan B. Enhancement of laccase production by Pleurotus ostreatus and its use for the decolorization of anthraquinone dye. Process Biochem. 2004;39:1415-1419.

39. Wang JW, Wu JH, Huang WY, Tan RX. Laccase production by Monotospora sp. an endophytic fungus in cynodondactylon. Bioresource Technol. 2006;97:786-789.

40. Lee $\mathrm{KH}$, Wi SG, Singh AP, Kim YS. Micromorphological characteristics of decayed wood and laccase produced by the brown-rot fungus Coniophoraputeana. J Wood Sci. 2004;68:3514-3521.

41. Brijwani K, Rigdon A, Vadlani PV. Fungal laccases: Production, function and applications in food processing. Enzyme Res. 2010;10. Article ID 149748.

42. Collins PJ, Dobson A. Regulation of laccase gene transcription in Trametes versicolor. Appl Environ Microbiol. 1997; 63:3444-3450.

43. Dong J, Zhang $\mathrm{YW}$, Zhang $\mathrm{RH}$, Huang WZ, Zhang YZ. Influence of culture conditions on laccase production and isoenzyme patterns in the white-rot fungus Trametes gallica. J. Basic Microbiol. 2005;45:190-198.

44. Revankar MS, Lele SS. Enhanced production of laccase using a new isolate of white rot fungus WR-1. Process Biochemistry. 2006;41:581-588.

45. Montiero MC, De Carvalho MEA. Pulp bleaching using laccase from $T$. versicolor under high temperature and alkaline conditions. Appl Biochem Biotechnol. 1998;70:983-993.

46. Buswell J, Cai Y, Chang S. Effect of nutrient and manganese on manganese peroxidase and laccase production by Lentinula (Lentinus) edodes. FEMS Microbiol Letters. 1995;128:81-87.

47. Shraddha, Shekher $R$, Sehgal $S$, Kamthania M, Kumar A. Laccase: Microbial sources, production, purification and potential biotechnological applications. Enzyme Research. 2011;11. ID 217861.
48. Keyser P, Kirk TK, Zeikus JG. Ligninolytic enzyme system of Phanerochaete chrysosporium: Synthesized in the absence of lignin in response to nitrogen starvation. J Bacteriol. 1978;135:790-797.

49. Wang J, Zheng X, Lin S, Lin J, Guo L, Chen $X$, Chen $Q$. Identification of differentially expressed genes involved in laccase production in tropical white-rot fungus Polyporus sp. PG15. J Basic Microbiol. 2014;54:142-151.

50. Fonseca MI, Shimizu E, Zapata PD, Villalba LL. Copper inducing effect on laccase production of white rot fungi native from Misiones (Argentina). Enzyme Microb Tech. 2010;46:534-539.

51. Manavalan T, Manavalan A, Thangavelu $\mathrm{KP}$, Heese $\mathrm{K}$. Characterization of optimized production, purification and application of laccase from Ganoderma lucidum. Biochem Eng J. 2013;70:106114.

52. Nakade K, Nakagawa Y, Yano A, Konno N, Sato T, Sakamoto Y. Effective induction of pblac1 laccase by copper ion in Polyporus brumalis ibrc05015. Fungal Biol. 2013;117:52-61.

53. Palmieri G, Giardina P, Bianco A, Capasso A, Sannia G. A novel white laccase from $P$. ostreatus. J Biol Chem. 2000;272:3130131307.

54. Baldrian P. Interactions of heavy metals with white-rot fungi. Enzyme Microb Technol. 2003;32:78-91.

55. Trupkin S, Levin L, Forchiassin F, Viale A. Optimization of a culture medium for ligninolytic enzyme production and synthetic dye decolorization using response surface methodology. J Ind Microb Biotechnol. 2003;30:682-690.

56. Sannia G, Faraco V, Giardina P, Palmieri G. Metal-activated laccase promoters. In Proceedings of the 81th International Conference on Biotechnology in the Pulp and Paper Industry. Helsinki, Finland; 2001.

57. Mann J, Markham J, Peiris P, SpoonerHart RN, Holford P, Nair NG. Use of olive mill wastewater as a suitable substrate for the production of laccase by Cerena consors. Int Biodeter Biodegr. 2015;99: 138-145.

58. Arias ME, Arenas M, Rodriguez J, Soliveri J, Ball AS, Hernandez M. Kraft pulp biobleaching and mediated oxidation of a non-phenolic substrate by laccase from 
Streptomyces cyaneus CECT 3335. Appl Environ Microbiol. 2003;69:1953-1958.

59. Givaudan A, Effose A, Faure D, Potier P, Bouillant ML, Bally R. Polyphenol oxidase from Azospirillum lipoferum isolated from rice rhizosphere: Evidence for laccase activity in non-motile strains of Azospirillum lipoferum. FEMS Microbiol Lett. 1993;108: 205-210.

60. Niladevi KN, Jacob N, Prema P. Evidence for a halotolerant-alkaline laccase in Streptomyces psammoticus: Purification and characterization. Process Biochem. 2008;43:654-660.

61. Couto SR, Toca-Herrera JL. Industrial and biotechnological applications of laccases: A review. Biotechnol Adv. 2006;24:500513.

62. Forootanfar H, Faramarzi MA, Shahverdi AR, Yazdi MT. Purification and biochemical characterization of extracellular laccase from the ascomycete Paraconiothyrium variabile. Bioresource Technol. 2011;102:1808-1814.

63. Dhakar K, Pandey A. Laccase production from a temperature and $\mathrm{pH}$-tolerant fungal strain of Tramete shirsuta (MTCC 11397). Enzyme Research. 2013;9. Article ID 869062.

64. Rosales E, Couto SR, Sanroman MA. Increased laccase production by Trametes hirsuta grown on ground orange peeling. Enzyme Microb Technol. 2007;4:12861290.

65. Heinzkill M, Bech L, Halkier T, Schneider $P$, Anke T. Characterization of laccase and peroxidase from wood-rotting fungi (Family: Coprinaceae). Appl Environ Microbiol. 1998;64:1601-1606.

66. Xavier AMRB, Evtuguin DV, Ferreira RMP, Amado FL. Laccase production for lignin oxidase activity. Proceedings $8^{\text {th }}$ Int Conf Biotechnol Helsinki, Finland; 2001.

67. Zheng ZM, Obbard JP. Effect of nonionic surfactants on elimination of polycyclic aromatic hydrocarbons (PAHs) in soil slurry by Phanerochaete chrysosporium. J Chem Technol. Biotechnol. 2001;76:423429.

68. Elsayed MA, Hassan MM, Elshafei AM, Haroun BM, Othman AM. Optimization of cultural and nutritional parameters for the production of laccase by Pleurotus ostreatus ARC280. Br. Biotechnol J. 2012;2:115-132.

69. Lestan D, Lestan $M$, Perdih $A$. Physiological aspects of biosynthesis of lignin peroxidases by Phanerochaete chrysosporium. Appl Environ Microbiol. 1994;60:606-612.

70. Cserhati T. Alkyl ethoxylated and alkylphenolethoxylated nonionic surfactants: Interaction with bioactive compounds and biological effects. Environ Health Perspective. 1995;103:358-364.

71. Diaz R, tellez-Tellez $M$, Bibbins-Martinez MD, Sanchez C, Diaz-Godinez G, SorianoSantos J. Influence of initial $\mathrm{pH}$ of the growing medium on the activity, production and expression profiles of laccases produced by Pleurotus ostreatus in submerged fermentation. Electron J Biotechnol. 2013;16:6.

72. Strong PJ. Improved laccase production by Trametes pubescens MB89 in distillery wastewaters. Enz. Res; 2011. Article ID 379176.

73. Janusz G, Rogalski J, Barwinska M, Szczodrak J. Effects of culture conditions on production of extracellular laccase by Rhizoctonia practical. Polish J Microbiol. 2006;55:309-319.

74. Kocyigit A, Pazarbasi MB, Yasa I, Ozdemir G, Karaboz I. Production of laccase from Tramete strogii TEM H2: A newly isolated white rot fungus by air sampling. J Basic Microbiol. 2012;52:661-669.

75. Han MJ, Choi HT, Song HG. Purification and characterization of laccase from the white rot fungus Trametes versicolor. J Microbiol. 2005;43:555-560.

76. Ravikumar G, Gomathi D, Kalaiselvi M, Uma C. Production, purification and partial characterization of laccase from the mushroom Hypsizygus ulmarius. Int $\mathrm{J}$ Pharm Bio Sci. 2012;3:355-365.

77. Chhaya U, Gupte A. Effect of different cultivation conditions and inducers on the production of laccase by the litter-dwelling fungal isolates Fusarium incarnatum LD-3 under solid substrate fermentation. Ann. Microbial. 2013;63:215-223.

78. Mansur M, Arias ME, Copa-Patino JL, Flardh M, Aldo-Gonzalez E. The white rot fungus Pleurotus ostreatus secretes laccase isozymes with different substrate specificities. Mycologia. 2003;95:10131020.

79. Velazquez L, Tellez-Tellez M, Diaz R, Bibbins-Martinez MD, Loera O, Sanchez C, Tlecuitl-Beristain S and Diaz-Godinez G. Laccase Isoenzymes of Pleurotus ostreatus grown at different $\mathrm{pH}$ in solid- 
state fermentation using polyurethane foam as support. Annual Research and Review in Biology. 2014;4:25662578.

80. Gianfreda L, Xu F, Bollag JM. Laccases: A useful group of oxidoreductive enzymes. Biorem. J. 1999;3:1-25.

81. Arora DS, Gill PK. Laccase production by some white rot fungi under different nutritional conditions. Bioresource Technol. 2000;73:283-285.

82. Shankar S, Shikha S. Laccase production and enzymatic modification of lignin by a novel Peniophora sp. Appl. Biochem Biotechnol. 2012;166:1082-1094.
83. Poojary H, Mugeraya G. Optimization of critical medium components using response surface methodology for laccase production by Peniophora sp. hpF04. J Microb Biotechnol. 2012;2:46-56.

84. Swamy J, Ramsay AJ. Effects of $\mathrm{Mn}^{2+}$ and $\mathrm{NH}_{4}{ }^{+}$concentrations on laccase and manganese peroxidase production and amaranth decoloration by Trametes versicolor. Appl Microbiol Biotechnol. 1999:51:391-395.

85. Jang MY, Ryu WR, Cho MH. Laccase production from repeated batch cultures using free mycelia of Trametes sp. Enzyme Microb Technol. 2002;30:741-746.

(c) 2016 Ire and Ahuekwe; This is an Open Access article distributed under the terms of the Creative Commons Attribution License (http://creativecommons.org/licenses/by/4.0), which permits unrestricted use, distribution, and reproduction in any medium, provided the original work is properly cited.

Peer-review history:

The peer review history for this paper can be accessed here: http://sciencedomain.org/review-history/15210 